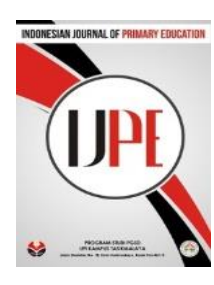

\title{
Seni Mural untuk Meningkatkan Minat Membaca di Perpustakaan SD Laboratorium Percontohan UPI Tasikmalaya
}

\author{
Tessa Assyfah ${ }^{1}$, Momoh Halimah ${ }^{2}$, Rosarina Giyartini ${ }^{3}$ \\ Universitas Pendidikan Indonesia Kampus Tasikmalaya \\ *Corresponding author: tessaassy2323@gmail.com¹, momohhalimah@upi.edu ${ }^{2}$, devicarasvati@gmail.com³
}

Diterima 21 Maret 2019; Direview 20 April 2019; Diterima 5 Mei 2019

Diterbitkan online 25 Juni 2019

\begin{abstract}
This research is conducted on the basis of mural arts applied in the library to the amount of reading interest of students in elementary school library, but the factin the field of mural art has not been optimally applied in adjusting facilities and infrastructure owned by educational unit with the growth of learners. So the intereset of visiting and reading books in the library owned by students is quite low. This research is done to get empirical evidence of mural art able to increase reading interest in the library Laboratory Elementary School of UPI Tasikmalaya. This research is done in the form of qualitative approach. The research design uses descriptive analysis design. Based on data analysis in this study obtained the conclusion that: mural art can increase reading interest in the library Laboratory Elementary School of UPI Tasikmalaya, because most of them like and have a big attention to mural art, so it can attract students to visit and read books in the library. Based on the results of this research, it is advisable for librarians and teachers in order to optimize the facilities and infrastructure owned by educational units in accordance with the growth and development of learners, one of them by applying the mural art in the libraryas an alternative way to increase students reading interest.
\end{abstract}

Keywords: Mural Arts, Reading Interest, Library.

\begin{abstract}
Abstrak
Penelitian ini dilakukan atas dasar seni mural yang diterapkan di perpustakaan terhadap jumlah minat membaca siswa di perpustakaan sekolah dasar, namun fakta di lapangan seni mural belum secara optimal diterapkan dalam menyesuaikan sarana dan prasarana yang dimiliki satuan pendidikan dengan pertumbuhan serta perkembangan peserta didik. Sehingga minat mengunjungi dan membaca buku di perpustakaan yang dimiliki siswa cukup rendah. Penelitian ini dilakukan untuk mendapatkan bukti empiris seni mural mampu meningkatkan minat membaca di perpustakaan SD Laboratorium Percontohan UPI Tasikmalaya. Penelitian dilakukan dalam bentuk pendekatan kualitatif. Desain penelitian menggunakan desain analisis deskriptif. Berdasarkan analisis data dalam penelitian ini diperoleh kesimpulan bahwa: seni mural mampu meningkatkan minat membaca di perpustakaan SD Laboratorium Percontohan UPI Tasikmalaya, karena sebagian besar menyukai dan mempunyai perhatian yang besar terhadap seni mural, sehingga dapat menarik minat siswa untuk mengunjugi dan membaca buku di perpustakaan. Berdasarkan hasil penelitian tersebut, disarankan bagi pustakawan dan guru agar dapat mengoptimalkan sarana dan prasarana yang dimiliki satuan pendidikan sesuai dengan pertumbuhan dan perkembangan peserta didik. Salah satunya dengan menerapkan seni mural di perpustakaan sebagai salah satu cara alternatif untuk meningkatkan minat membaca siswa di perpustakaan.
\end{abstract}

Kata Kunci: Seni Mural, Minat Membaca, Perpustakaan.

\section{PENDAHULUAN}

Pendidikan merupakan sarana untuk mengembangkan potensi, minat serta bakat yang dimiliki siswa. Menurut UndangUndang No. 20 tentang Sistem Pendidikan Nasional tahun 2003 menjelaskan bahwa pendidikan berfungsi mengembangkan kemampuan dan membentuk watak serta peradaban bangsa yang bermartabat dalam rangka mencerdaskan kehidupan bangsa, bertujuan untuk berkembangnya potensi peserta didik agar menjadi manusia yang beriman dan bertakwa kepada Tuhan Yang Maha Esa, berakhlak mulia, sehat, berilmu, 
cakap, kreatif, mandiri, dan menjadi warga negara yang demokratis serta bertanggung jawab.

Berdasarkan hal tersebut, pendidikan tentunya mampu mengembangkan kemampuan serta potensi yang dimiliki siswa, salah satunya adalah pengembangan kemampuan dan potensi melalui pendidikan seni, namun potensi yang dimiliki setiap tersebut tentu berbeda antara satu dengan yang lainnya. Maka terdapat tiga bidang seni di sekolah dasar, salah satunya adalah seni rupa. Seni rupa merupakan salah satu bagian ilmu seni yang mewadahi ekspresi melalui media, baik menyerupai objek maupun pengabstraksian ekspresi penyuka seni rupa itu sendiri. Hal ini selaras dengan pendapat Bahtiar (2015, hlm. 2) bahwa:

Seni rupa adalah cabang seni yang membentuk karya seni dengan media yang ditangkap oleh mata dan dirasakan dengan rabaan. Seni rupa juga diartikan sebagai hasil ciptaan kualitas, hasil, ekspresi, atau alam keindahan atau segala hal yang melebihi keasliannya serta klasifikasi objek-objek terhadap kriteria tertentu yang diciptakan menjadi suatu struktur sehingga dapat dinikmati menggunakan indera mata dan peraba.

Seni rupa mempunyai beberapa cabang ilmu, salah satu jenis tersebut yaitu cabang ilmu seni rupa berdasarkan wujudnya adalah seni rupa dua dimensi, seni rupa dua dimensi merupakan salah satu contoh karya seni rupa yang hanya dapat dilihat dengan satu arah saja yaitu dari arah depan.

Mengenai pengertian seni rupa dua dimensi, Graa (2015, hlm.3) berpendapat bahwa "Karya seni rupa dua dimensi adalah karya seni rupa yang diterapkan pada bidang datar seperti gambar, lukisan, dan sejenisnya".

Seni rupa dua dimensi memiliki contoh karya salah satunya adalah seni lukis yang merupakan karya seni rupa dua dimensi yang dibuat dalam bidang datar, seperti kertas, kanvas, serta kaca dengan menggunakan cat sebagai alat lukisnya. Seni lukis mempunyai komposisi perpaduan warna yang dapat mengekspresikan makna atau arti dari lukisan itu sendiri.

Penggunaan warna-warna yang mampu menarik perhatian seseorang yang melihatnya tentu mampu menggugah gairah orang tersebut. Maka penggunaan warna di suatu ruangan khususnya ruangan belajar seperti perpustakaan mampu meningkatkan minat seseorang tersebut terhadap suatu obyek.

Suherman (2016, hlm. 58) yang menyatakan bahwa“...penggunaan warna di perpustakaan tidak dapat disepelekan. Warna dapat mempengaruhi psikologis pengunjung sehingga merasa nyaman dan betah berada di perpustakaan, serta selalu ingin datang. Selain itu warna pun dapat merubah citra negatif perpustakaan yang selama ini identik dengan gudang buku yang tidak menarik untuk dikunjungi”. 
Mengacu pada hal tersebut, menerapkan perpaduan warna yang menarik dalam lukisan dinding atau sering disebut dengan seni mural serta disebut juga dengan desain interior di perpustakaan adalah salah satu upaya yang dapat dilakukan pustakawan atau sekolah untuk mempengaruhi bahkan meningkatkan minat belajar siswa. Karena ruang perpustakaan di sekolah merupakan salah satu ruangan sekolah pilihan siswa yang mampu menyediakan sumber-sumber pengetahuan bagi siswa. Melalui aktivitas yang aktif dalam kegiatan membaca buku-buku perpustakaan, tentunya siswa dapat secara mandiri dengan menggali informasi sebanyak apapun yang ia ingin ketahui. Hal ini pun selaras dengan pendapat berikut “...Perpustakaan sekolah bagi anak merupakan wadah untuk mengetahui referensi, berbagai materi dan bacaan-bacaan lainnya." Musthafa (dalam Suherman, 2016, hlm. 32). Oleh karena itu, sebuah sekolah tentunya harus menyediakan perpustakaan untuk dijadikan ruangan yang mampu menjadi tempat fasilitator bagi siswa menggali pengetahuan.

Mengingat pentingnya perpustakaan bagi siswa, khususnya Sekolah Dasar, maka pihak sekolah perlu untuk memaksimalkan display perpustakaan dengan menerapkan desain interior yang dalam hal ini adalah seni mural, hal ini juga selaras dengan pendapat Ajie, D.M. (2011, hlm. 78) yang menyatakan bahwa:
Desain interior perpustakaan perlu ditata dengan baik karena pemustaka atau pemakai ruang menghendaki adanya suasana yang nyaman, baik, indah dan mampu melayani segala kebutuhan secara fisik maupun spiritual/emosional. Untuk itu desain interior perpustakaan harus mampu memberikan perlindungan kenyamanan, keamanan dan menimbulkan rasa betah bagi pemustaka.

Dengan suasana yang nyaman dan indah di perpustakaan siswa dapat mengembangkan minatnya terhadap membaca. Berawal dari rasa tertarik, kagum serta ingin mengunjungi perpustakaan, akan muncul minat dari dalam dirinya. Maka dengan besarnya minat membaca, siswa pun dapat mengoptimalkan ketekunan dalam kegiatan belajarnya guna menunjang penambahan kekayaan pengetahuan yang mereka miliki. Karena dengan tumbuhnya minat seseorang, akan melahirkan perhatian untuk melakukan segala sesuatu dengan tekun dalam jangka waktu yang lama, lebih berkonsentrasi, mudah untuk mengingat dan tidak mudah bosan dengan apa yang dipelajarinya, Sugiyarti (dalam Jayanti, 2012, hlm. 5).

Minat membaca siswa di perpustakaan SD Laboratorium Percontohan UPI Tasikmalaya cukup rendah, hal ini ditandai dengan studi pendahuluan yang telah dilakukan peneliti dengan mewawancarai pustakawan dan seorang siswa karena hanya $30 \%$ siswa dari jumlah seluruh siswa yang mengunjungi 
perpustakaan dalam satu bulan terakhir. Menyinggung teori-teori yang telah peneliti paparkan diatas, maka menerapkan seni mural di perpustakaan adalah upaya untuk meningkatkan rendahnya minat membaca siswa.

Berdasarkan pemaparan tersebut, peneliti melakukan penelitian yang berjudul "Seni Mural untuk Meningkatkan Minat Membaca di Perpustakaan SD Laboratorium Percontohan UPI Tasikmalaya”. Diharapkan bahwa penelitian ini mampu meningkatkan minat membaca siswa di perpustakaan serta menjadikan perpustakaan sebagai tempat utama untuk menggali informasi sebanyak mungkin

\section{METODE PENELITIAN}

Penelitian ini menggunakan metode penelitian analisis deskriptif dengan pendekatan kualitatif. Mukhtar (2013, hlm. 29) penelitian desktiptif kualitatif adalah sebuah penelitian yang dimaksud untuk mengungkap sebuah fakta secara alamiah. Sehingga dalam penelitian ini sangat memperhatikan proses, peristiwa atau aktivitas. Metode ini hanya memaparkan peristiwa atau aktivitas yang terjadi, dan tidak menguji hipotesis. Penelitian ini timbul karena ada suatu peristiwa atau aktivitas yang menarik perhatian peneliti, namun belum ada kerangka teori untuk menjelaskannya. Penelitian ini bertujuan untuk mengungkapkan dan menjelaskan mengenai peningkatan minat membaca di perpustakaan
SD Laboratorium Percontohan Tasikmalaya.

Sekolah Dasar Laboratorium Percontohan UPI Tasikmalaya menerapkan seni mural di dinding perpustakaannya, dengan mengusung sekolah bertema kearifan lokal, Sekolah Dasar Laboratorium Percontohan UPI Tasikmalaya mampu memfasilitasi siswa untuk mengoptimalkan potensi yang dimiliki. Dengan diterapkannya seni mural sebagai cara untuk meningkatkan minat membaca siswa di perpustakaan, Sekolah Dasar Laboratorium menjadi salah satu satuan pendidikan yang memperhatikan tumbuh kembang anak terlebih perkembangan psikisnya. Melalui penelitian kualitatif, peneliti mengungkap fenomena tentang meningkatknya minat membaca siswa di perpustakaan Sekolah Dasar Laboratorium Percontohan UPI Tasikmalaya. Peneliti sebagai instrumen penelitian bertidak mengumpulkan data, mendeskripsikan data dan menganalisis data yang di peroleh mengenai peningkatan minat membaca siswa di perpustakaan melalui diterapannya seni mural di dinding perpustakaan Sekolah Dasar Laboratorium Percontohan UPI Tasikmalaya melalui wawancara, penyebaran lembar angket serta dokumentasi.

Ciri dari penelitian kualitatif adalah bersifat deskripsi-analisis sehingga data di peroleh dalam bentuk narasi deskripsi. Penelitian analisis deskriptif yang dilakukan peneliti terhadap subjek penelitian adalah 
untuk menjawab berbagai pertanyaan how. Dengan demikian, penelitian ini berfokus pada pertanyaan bagaimana kondisi minat membaca siswa di perpustakaan SD Laboratorium Percontohan UPI Tasikmalaya? Bagaimana kondisi minat membaca siswa di perpustakaan SD Laboratorium Percontohan UPI Tasikmalaya? Serta bagaimanakah seni mural meningkatkan minat membaca di perpustakaan SD laboratorium Percontohan UPI Tasikmalaya?

\section{HASIL DAN PEMBAHASAN}

\section{Gambaran Penerapan Seni Mural di} Perpustakaan SD Laboratorium Percontohan UPI Tasikmalaya

Gambaran seni mural di perpustakaan SD Laboratorium Percontohan UPI Tasikmalaya akan dipaparkan secara deskriptif oleh penulis. Data penerapan seni mural di perpustakaan SD Laboratorium Percontohan UPI Tasikmalaya (Variabel X) diperoleh dari 30 siswa yang menjawab lembar angket variabel penerapan seni mural yang berjumlah 4 item yang ditentukan berdasarkan skor hasil angket yang telah ditentukan peneliti.

Skor akhir hasil jawaban angket terkait penerapan seni mural disajikan pada grafik berikut:

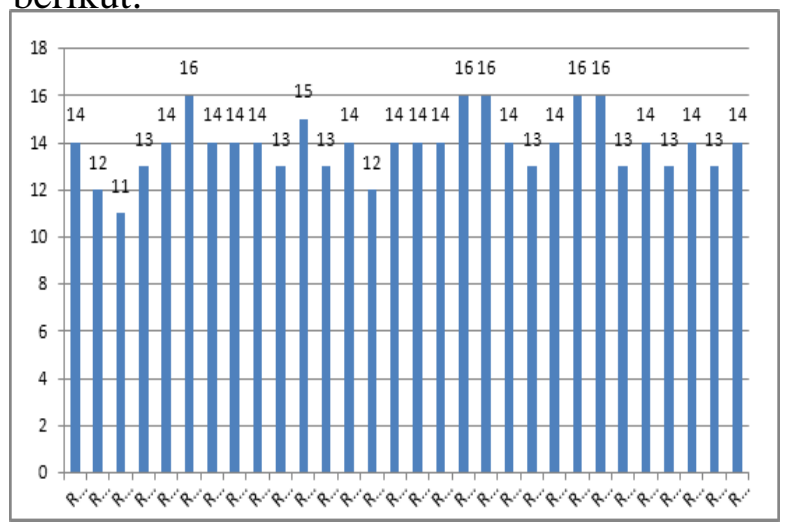

Berdasarkan grafik diatas, dapat diperoleh skor yang sering muncul adalah 14, juga skor minimumnya adalah sebesar 11 pada S3. Sedangkan skor maksimumnya adalah sebesar 16 yaitu pada S6, S18. S19, S23 dan S24. Berdasarkan data tersebut, dapat di deskripsikan gambaran umum mengenai penerapan seni mural di perpustakaan SD Laboratorium Percontohan UPI Tasikmalaya cukup tinggi.

Untuk memudahkan peneliti mendeskripsikan data dalam gambar diatas, peneliti menyajikan data tersebut ke dalam grafik dibawah ini:

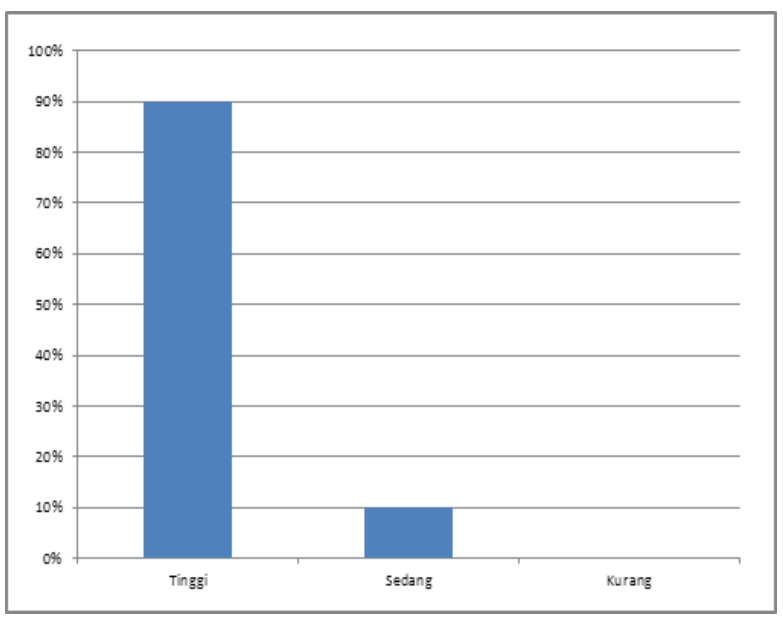

Berdasarkan gambar grafik presentase diatas, dapat diketahui bahwa sebagian besar responden menjawab tingkat penerapan seni mural di SD Laboratorium Percontohan UPI Tasikmalaya termasuk kategori tinggi. Dari keseluruhan responden yang berjumlah 30 orang, sebanyak 27 responden (90\%) menjawab bahwa tingkat penerapan seni mural di SD Laboratorium Percontohan UPI Tasikmalaya termasuk kategori tinggi, serta sebanyak 3 responden (10\%) menjawab 
bahwa tingkat penerapan seni mural di SD Laboratorium Percontohan UPI Tasikmalaya termasuk kategori sedang.

Dengan demikian, gambaran mengenai penerapan seni mural di perpustakaan SD Laboratorium Percontohan UPI Tasikmalaya dapat diketahui, yakni bahwa sebagian besar siswa kelas I-IV merasa tingkat penerapan seni mural di perpustakaan cukup tinggi, atau boleh dikatakan seni mural mampu menarik perhatian siswa.

Hal ini ditandai dengan sering munculnya skor tertinggi dibandingkan skor terendah dalam skor akhir hasil jawaban angket siswa tersebut. Karena sebanyak 27 orang siswa menjawab bahwa penerapan seni mural, dan persepektif mereka terhadap penerapan seni mural di perpustakaan SD Laboratorium Percontohan UPI Tasikmalaya cukup tinggi dirasakan. Itu artinya bahwa sebagian siswa SD Laboratorium Percontohan UPI Tasikmalaya memiliki perspektif tinggi dan minat ketertarikan yang tinggi pula terhadap seni mural yang diterapkan di perpustakaan SD Laboratorium Percontohan UPI Tasikmalaya.

Sebagian siswa berjumlah 3 orang, memberi jawaban angket mengenai penerapan seni mural. Itu artinya, sebagian kecil siswa di SD Laboratorium Percontohan UPI Tasikmalaya mempunyai perspektif yang tidak terlalu tinggi dan minat yang tidak terlalu besar terhadap seni mural yang diterapkan di perpustakaan SD Laboratorium Percontohan UPI Tasikmalaya.

\section{Gambaran Minat Membaca di Perpustakaan SD Laboratorium Percontohan UPI Tasikmalaya \\ Data minat membaca di perpustakaan SD}

Laboratorium Percontohan UPI Tasikmalaya (Variabel Y) diperoleh dari 30 siswa yang menjawab angket variabel penerapan seni mural yang berjumlah 7 item dan sebelumnya telah ditentukan berdasarkan skor hasil angket yang telah ditentukan peneliti. dapat diketahui gambaran skor akhir hasil lembar angket minat membaca di perpustakaan SD Laboratorium Percontohan UPI Tasikmalaya dapat disajikan dalam grafik berikut:

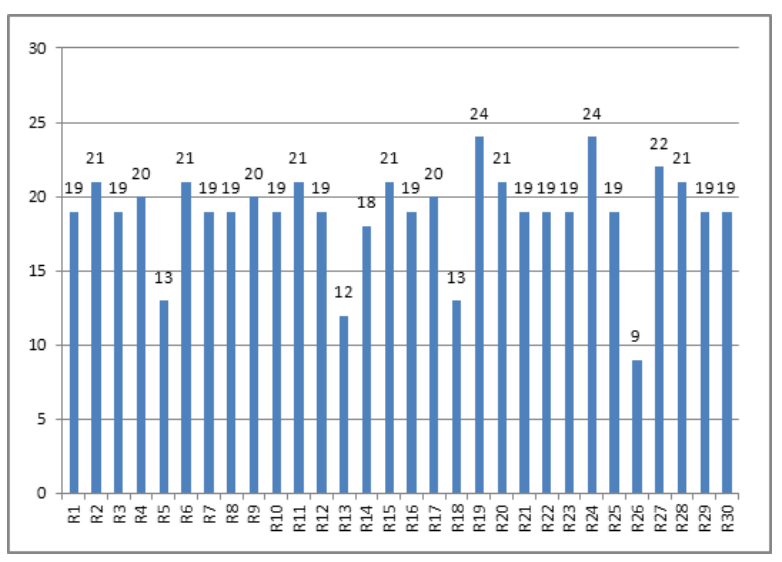

Berdasarkan gambar grafik diatas, dapat diperoleh skor yang sering muncul adalah 19, skor minimumnya adalah 9 pada S26, sedangkan skor maksimumnya adalah 24 yaitu pada S19 dan S24. Dapat diketahui bahwa sebagian besar siswa sebagai responden penjawab pernyataan-pernyataan dalam lembar angket yang dibagikan peneliti mempunyai minat membaca di perpustakaan SD Laboratorium yang cukup tinggi. Sebagian kecil dari siswa SD yang menjawab 
pernyataan-pernyaataan dalam lembar angket mempunyai minat membaca di perpustakaan SD Laboratorium Percontohan UPI Tasikmalaya sangat tinggi

Untuk memudahkan peneliti menganalisis deskripsikan gambaran umum mengenai minat membaca di perpustakaan SD Laboratorium Percontohan UPI Tasikmalaya, maka peneliti menyajikannya data-data yang telah ditemukan sebelumya ke dalam grafik berikut:

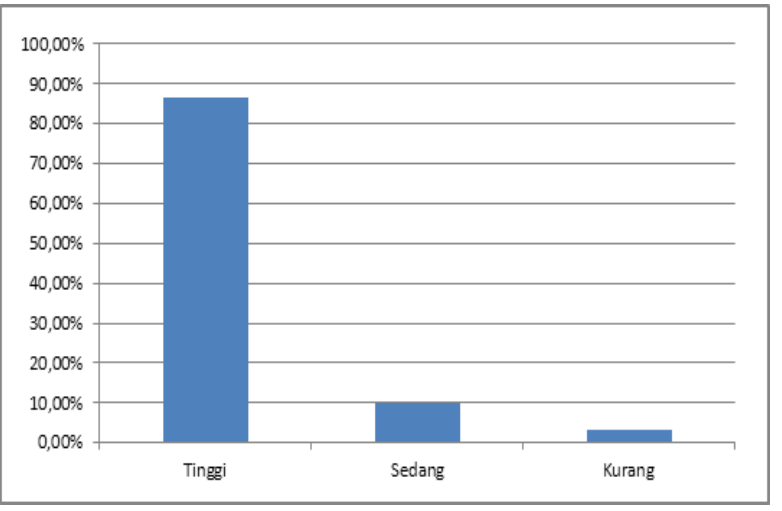

Berdasarkan grafik diatas, dapat dilihat bahwa dari 30 orang responden angket, sebanyak 26 orang responden $(86,7 \%)$ memiliki minat membaca yang tinggi di perpustakaan, sebanyak 3 orang responden (10\%) memiliki minat membaca yang sedang di perpustakaan, serta 1 orang responden $(3,3 \%)$ memiliki minat membaca yang kurang di perpustakaan.

Melalui penjabaran grafik tersebut, peneliti mampu mendeskripsikan gambaran umum mengenai minat membaca di perpustakaan. Bahwa sebagian besar siswa yakni sebanyak 26 siswa dari 30 siswa yang mengisi lembar pernyataan angket mempunyai minat membaca yang tinggi. Siswa memiliki ketertarikan membaca yang tinggi, minat membaca buku pengetahuan yang tinggi, rasa kepedulian akan perpustakaan yang tinggi pula, dan tingkat antusiasme untuk mengunjungi perpustakaan yang tinggi.

Sebanyak 3 orang siswa dari 30 siswa yang menjawab pernyataan-pernyataan dalam lembar angket mempunyai minat membaca yang cukup tinggi, ketertarikan untuk membaca cukup tinggi, minat membaca buku pengetahuan cukup tinggi, rasa kepedulian akan memelihari kebersihan perpustakaan cukup tinggi,dan tingkat antusiasme untuk mengunjungi perpustakaan cukup tinggi.

Sedangkan 1 orang siswa dari 30 siswa yang menjawab pernyataan dalam lembar angket mempunyai minat membaca rendah, ketertarikan untuk membaca rendah, ketertarikan untuk membaca rendah, rasa kepedulian untuk menjaga kebersihan perpustakaan rendah, dan tingkat antusiasme untuk mengunjungi perpustakaan rendah.

Berdasarkan pemaparan mengenai temuan tentang seni mural dan minat membaca di perpustakaan SD Laboratorium Percontohan UPI Tasikmalaya cukup tinggi. Siswa SD Laboratorium Percontohan UPI Tasikmalaya mempunyai persepektif yang cukup tinggi terhadap seni mural, juga memiliki potensi yang tinggi terhadap minat membaca di perpustakaan SD Laboratorium Percontohan UPI Tasikmalaya 


\section{Gambaran Mampunya Seni Mural Meningkatkan Minat Membaca di Perpustakaan SD Laboratorium Percontohan UPI Tasikmalaya}

Sebagaimana telah diketahui sebelumnya bahwa rumusan masalah penelitian yang ketiga adalah tentang bagaimana hubungan antara penerapan seni mural dengan meningkatnya minat membaca di SD Laboratorium Percontohan UPI Tasikmalaya, maka peneliti akan menjelaskan secara rinci pertanyaan tersebut secara analisis deskriptif.

Meningkatnya minat membaca siswa di perpustakaan SD Laboratorium Percontohan UPI Tasikmalaya salah satunya dipengaruhi oleh diterapkannya seni mural pada dinding perpustakaan. Siswa menjadi lebih mempunyai minat yang tinggi untuk mengunjungi dan membaca buku diperpustakaan. Berdasarkan gambaran umum mengenai penerapan seni mural dan minat membaca di perpustakaan, dapat diketahui bahwa seni mural mempunyai pengaruh yang cukup besar untuk menarik minat siswa mengunjungi dan membaca buku serta meminjam buku di perpustakaan.

Melalui ketertarikan siswa terhadap seni mural yang diterapkan pada dinding perpustakaan, tentu akan meningkatkan minatnya untuk mengunjungi. Hal ini berdampak positif bagi siswa, karena secara tidak sadar siswa mengunjungi perpustakaan tanpa harus ada paksaan dari guru maupun pustakawan SD Laboratorium Percontohan UPI Tasikmalaya. Siswa yang hanya memiliki minat terhadap gambar-gambar visual, akan mempunyai minat juga untuk mengunjungi perpustakaan dan membaca buku di dalam perpustakaan.

\section{SIMPULAN}

Kesimpulan yang dapat ditarik dari hasil penelitian ini, seni mural untuk meningkatkan minat membaca di perpustakaan SD Laboratorium Percontohan UPI Tasikmalaya adalah sebagai berikut:

1) Secara umum penerapan seni mural di perpustakaan SD Laboratorium Percontohan UPI Tasikmalaya termasuk ke dalam kategori tinggi. Itu artinya sebagian besar siswa SD Laboratorium Percontohan UPI Tasikmalaya merespon dengan baik dan menyukai diterapkannya seni mural di dinding perpustakaan.

2) Secara umum minat membaca siswa di perpustakaan SD Laboratorium Percontohan UPI Tasikmalaya berada pada kategori tinggi. Artinya, sebagian besar siswa SD Laboratorium Percontohan UPI Tasikmalaya memiliki minat terhadap membaca di perpustakaan.

3) Terdapat hubungan secara positif yaitu seni mural mampu meningkatkan minat membaca di perpustakaan, serta terdapat pengaruh yang signifikan antara penerapan seni mural dengan minat membaca di perpustakaan SD Laboratorium Percontohan UPI Tasikmalaya. Artinya semakin tinggi tingkat persepektif siswa terhadap penerapan seni mural atau desain interior yang diterapkan di perpustakaan, 
semakin tinggi pula minat membaca di perpustakaan. Akan tetapi, jika semakin rendah penerapan seni mural atau desain interior yang diterapkan di perpustakaan, maka akan tidak akan semakin rendah pula minat membaca di perpustakaan SD Laboratorium Percontohan UPI Tasikmalaya.

\section{DAFTAR PUSTAKA}

. 2017. Pedoman Penulisan Karya Ilmiah. Bandung: UPI

Abdurrahman, M. (2003) Pendidikan Bagi Anak Berkesulitan Belajar. Jakarta : Rineka Cipta

Badriah, S. (2014) Hubungan antara Penataan Ruang Perpustakaan terhadap Minat Belajar Siswa di Perpustakaan Retrieved from http://ejournal.upi.edu/

Bahtiar, A. Pendidikan Seni Rupa Sekolah Dasar Retrieved from http://academia.edu/pendidikan-senirupa-sekolah-dasar/

Donahue, D. M. (2011) Connecting Classroom With Mural Arts by the National Association for Multicultural Education
Graa, Sejarah Perkembangan Seni Rupa Retrieved from http://academia.edu/sejarah- perkembangan-seni-rupa/

Hurlock, Elizabeth B. 2010. Psikologi Perkembangan Jilid 2 ed 6. Jakarta: Erlangga

Iswandi, (2016) Seni Mural sebagai Unsur Politik dalam Kehidupan Sosial Retrieved from http://ejournal.uigm.ac.id/Besaung/articl e/

Jayanti, K. N. (2012) Pengaruh Penggunaan Alat Peraga Matematika terhadap
Minat Belajar Siswa dalam Mata Pelajaran Matematika (Skripsi) Program Pendidikan Guru Sekolah Dasar, Universitas Pendidikan Indonesia Kampus Tasikmalaya

Kuntjojo. 2009. Metodologi Penelitian. Kediri: Universitas Nusantara PGRI

Nuthpaturrahman. 2008. Minat Belajar Siswa dalam Mata Pelajaran Matematika pada Madrasah Tsanawiyah Ismaili Kambat Selatan Kecamatan Pandawan Kabupaten Hulu Sungai Tengah. Skripsi Sarjana pada Fakultas Pendidikan Islam Sekolah Tinggi Agama Islam Al Washiliyah Barabai. Barabai: Tidak diterbitkan

Purwanto, A. D. Peran Perpustakaan Sekolah dalam meningkatkan Mutu Pendidikan Retrieved from http://ejournal.upi.edu/

Rahim, F. (2011) Pengajaran Membaca di Sekolah Dasar. Jakarta : Bumi Aksara.

Rahim. 2005. Pengajaran Membaca di Sekolah Dasar. Padang: Bumi Aksara

Riduwan. 2009. Belajar Mudah Penelitian untuk Guru, Karyawan dan Peneliti Pemula. Bandung: Alfabeta

Siswoyo, dkk. 2007. Ilmu Pendidikan. Yogyakarta: UNY Press

Slameto. 2003. Belajar dan Faktor-Faktor yang Mempengaruhinya. Jakarta: Rineka Cipta

Sugiyono, (2016) Cara Mudah Menyusun: Skripsi, Tesis dan Disertasi. Bandung : Alfabeta

Sugiyono, (2016) Metode Penelitian Pendidikan. Bandung : Alfabeta

Sugiyono. 2010. Metode Penelitian Pendidikan. Bandung: Alfabeta

Suherman, (2016) Perpustakaan sebagai Jantung Sekolah. Bandung: LRC Foundation 
Sukayati dan Suharjana. 2009. Pemanfaatan

Alat Peraga Matematika dalam

Pembelajaran di SD. Yogyakarta

Tampubolon, (1993) Mengembangkan Minat dan Kebiasaan Membaca pada Anak. Bandung: Angkasa

Tarigan. 2008. Membaca Sebagai Suatu Keterampilan Berbahasa. Bandung: Angkasa 